\title{
PHYTOCHEMICAL INVESTIGATION OF RUMEX THYRSIFLORUS FINGERH.
}

\author{
SHORT COMMUNICATION \\ Orsolya Orbán-Gyapai, ${ }^{1}$ Peter Forgo, ${ }^{1}$ Judit Hohmann ${ }^{1,2}$ and Andrea Vasas ${ }^{1 *}$ \\ ${ }^{1}$ Department of Pharmacognosy, University of Szeged, H-6720 Szeged, Hungary \\ ${ }_{2}^{2}$ Interdisciplinary Centre of Natural Products, University of Szeged, H-6720 Szeged, Hungary
}

(Received: November 17, 2016; accepted: January 10, 2017)

\begin{abstract}
In the course of our pharmacological screening of Polygonaceae species occurring in the Carpathian Basin the extracts prepared from the roots of Rumex thyrsiflorus showed promising antiproliferative, xanthine oxidase inhibitory and antibacterial activities. The present work deals with the isolation of compounds from the root of the plant. After multistep separation process, four compounds were obtained from the $n$-hexane, chloroform and ethyl acetate soluble fractions of the methanol extract of the root. The structures of the isolated compounds were determined as 1-palmitoylglycerol, $\beta$-sitosterol, (-)-epicatechin, and procyanidin B5.
\end{abstract}

Keywords: Rumex thyrsiflorus - Polygonaceae - phenolic compounds - procyanidin

Rumex genus (sorrel), belonging to the Polygonaceae family, comprises about 200 species distributed worldwide. Several species are used traditionally either as foods (soup or salad) or as healing agents $[15,17]$. The aerial parts, leaves and roots of the plants (e.g. $R$. acetosa, $R$. acetosella, $R$. alpinus, $R$. confertus, $R$. crispus and $R$. obtusifolius) are used in traditional medicine for the treatment of different health disorders such as infections, oedema, mild diabetes, jaundice, diarrhoea, constipation, as an antihypertensive, diuretic, and analgesic drug, and in case of skin disorders and inflammation $[1,4,5,17]$. Rumex species are characterized by the accumulation of anthraquinones, naphthalenes, flavonoids, and stilbenoids [17].

Pharmacological investigation of Polygonaceae species occurring in the Carpathian Basin resulted in the discovery of antiproliferative, xanthine oxidase (XO) inhibitory and antibacterial activity of numerous species. Among them Rumex thyrsiflorus Fingerh. possessed remarkable effect in all three test systems [in the antiproliferative assay the $\mathrm{CHCl}_{3}$ fraction of the roots $(96.20 \%$ inhibition on $\mathrm{A} 431$, and $88.55 \%$ inhibition on MCF7 cell lines, at a concentration of $30 \mu \mathrm{g} / \mathrm{mL}$ ) [7]; in the XO inhibitory assay the remaining aqueous fraction of both of the herb $\left(\mathrm{IC}_{50}=78.45 \mu \mathrm{g} / \mathrm{mL}\right)$ and the roots $\left(\mathrm{IC}_{50}=39.25 \mu \mathrm{g} / \mathrm{mL}\right)[12]$; and in the antibacterial test the remaining aqueous fraction of the roots (inhibitory zones: $11.3 \mathrm{~mm}$ (Staphylococcus epidermidis),

*Corresponding author; e-mail address: vasasa@pharmacognosy.hu 
$12.3 \mathrm{~mm}$ (S. aureus), $9.7 \mathrm{~mm}$ (MRSA), $10.3 \mathrm{~mm}$ (Bacillus subtilis), and $10.7 \mathrm{~mm}$ (Moraxella catarrhalis)] [13].

The aim of the present work was the phytochemical investigation of R. thyrsiflorus, in order to identify the characteristic secondary metabolites of the plant which can be responsible for the pharmacological activities. The roots were collected, in Szeghalom, Hungary $\left(47^{\circ} 0{ }^{\prime} 33.78^{\prime} \mathrm{N}, 21^{\circ} 10^{\prime} 48.89^{\prime \prime} \mathrm{E}\right)$. Botanical identification of the plant material was performed by Gusztáv Jakab (Institute of Environmental Sciences, Szent István University, Szarvas, Hungary). A voucher specimen (No. 803) has been deposited at the Department of Pharmacognosy, University of Szeged, Szeged, Hungary.

The dried roots of $R$. thyrsiflorus $(850 \mathrm{~g})$ were percolated with methanol $(15 \mathrm{~L})$ at room temperature. The crude extract was concentrated in vacuo to $200 \mathrm{~mL}$ and solvent-solvent partition was performed with $n$-hexane, $\mathrm{CHCl}_{3}$ and EtOAc $(3 \times 500 \mathrm{~mL}$ each). From $n$-hexane fraction $\left(5.2 \mathrm{~g}\right.$ ) compound 2 was crystallized. The $\mathrm{CHCl}_{3}$ fraction (3.6 g) was separated by reverse phase MPLC (medium pressure liquid chromatography) [Büchi, Pump Manager C615, Pump Module C605, using prepacked RP-cartridge (RP18ec sorbent, $40-63 \mu \mathrm{m}]$ ) with gradient mixtures of $\mathrm{MeOH}-\mathrm{H}_{2} \mathrm{O}$ (from 1:9 to 9:1) to yield 10 subfractions. Subfraction 2 was further purified by rotation planar chromatography (RPC) (Chromatotron instrument, Model 8924, Harrison Research, USA) on silica gel $60 \mathrm{GF}_{254}$ with the gradient system of $\mathrm{CH}_{2} \mathrm{Cl}_{2}-\mathrm{MeOH}$ (from 9:1 to 1:1), and 4 fractions were obtained. Fraction 2 was purified by TLC using the mobile phase EtOAc- $\mathrm{MeOH}-\mathrm{H}_{2} \mathrm{O}(100: 16: 12)$ to yield compound 3. The EtOAc fraction (47 g) was separated by vacuum liquid chromatography (VLC) on silica gel with gradient mixtures of $\mathrm{CHCl}_{3}-\mathrm{MeOH}$ (from 95:5 to 1:1). Fractions with similar composition were combined according to TLC monitoring to yield 10 main fractions. From fraction 2 compound 1 was crystallized. Fraction 6 was further purified by gel filtration on Sephadex LH-20 with $\mathrm{CH}_{2} \mathrm{Cl}_{2}-\mathrm{MeOH}$ (1:1), and 7 subfractions were obtained. Subfraction 5 was separated by RPC using EtOAc-EtOH- $\mathrm{H}_{2} \mathrm{O}$ (4:1:5) and compound $\mathbf{4}$ was isolated.

Structures of the compounds (1-4) were established by MS (API 2000 MS/MS equipped with an electrospray (ESI) interface) and 1D and 2D NMR spectroscopy [Bruker Avance DRX 500 spectrometer, at $500 \mathrm{MHz}\left({ }^{1} \mathrm{H}\right)$ and $125 \mathrm{MHz}\left({ }^{13} \mathrm{C}\right), \delta$ in ppm rel. to TMS as internal standard, $J$ in $\mathrm{Hz}$, solvent $\mathrm{CD}_{3} \mathrm{OD} ; 2 \mathrm{D}$ experiments were performed with a standard Bruker software]. The high resolution MS spectra for the new compound (1) was acquired on a Thermo Scientific Q-Exactive Plus Orbitrap mass spectrometer equipped with ESI ion source in positive ionization mode. The resolution was over $1 \mathrm{ppm}$. The data were acquired and processed with the MassLynx software.

Compound 1 was isolated as yellow oil. Its HRESIMS provided the molecular formula, $\mathrm{C}_{19} \mathrm{H}_{38} \mathrm{O}_{4}$, through the presence of a peak at $\mathrm{m} / z 331.1883[\mathrm{M}+\mathrm{H}]^{+}$(calcd. for $\left.\mathrm{C}_{19} \mathrm{H}_{39} \mathrm{O}_{4}, 331.1904\right)$. NMR $\delta_{\mathrm{H}}\left(500 \mathrm{MHz}, \mathrm{CDCl}_{3}\right.$, data measured for the first time in this solvent) $4.20(1 \mathrm{H}, \mathrm{dd} J=11.7,4.6 \mathrm{~Hz}, \mathrm{H}-1 \mathrm{a}), 4.15(1 \mathrm{H}, \mathrm{dd}, J=11.7,6.2 \mathrm{~Hz}$, $\mathrm{H}-1 \mathrm{~b}), 3.93(1 \mathrm{H}$, quint, $J=5.7 \mathrm{~Hz}, \mathrm{H}-2), 3.70(1 \mathrm{H}, \mathrm{dd}, J=11.5,3.9 \mathrm{~Hz}, \mathrm{H}-3 \mathrm{a}), 3.60$ $(1 \mathrm{H}, \mathrm{dd}, J=11.5,5.8 \mathrm{~Hz}, \mathrm{H}-3 \mathrm{~b}), 2.35(2 \mathrm{H}, \mathrm{t}, J=7.5 \mathrm{~Hz}, \mathrm{H}-2$ '), 1.63 (2H, quint, 
$\left.J=7.5 \mathrm{~Hz}, \mathrm{H}-3^{\prime}\right), 1.29$ (2H, m, H-15'), 1.25 (22H, m, H-4'-H-14'), 0.88 (3H, t, $\left.J=6.9 \mathrm{~Hz}, \mathrm{H}-16^{\prime}\right) ; \delta_{\mathrm{C}}\left(125 \mathrm{MHz}, \mathrm{CDCl}_{3}\right) 174.4\left(\mathrm{C}-1^{\prime}\right), 70.3(\mathrm{C}-2), 65.1(\mathrm{C}-1), 63.3$ (C-3), 34.1 (C-2'), 31.9 (C-15'), $4 \times 29.7$ (C-11'-14'), $2 \times 29.6$ (C-9', C-10'), $2 \times 29.4$ (C7', C-8'), 29.3 (C-6'), 2×29.1 (C-4', C-5'), 24.9 (C-3'), 14.1 (C-16'). The ${ }^{1} \mathrm{H}$ NMR data were in agreement with data reported in the literature for palmitoleic acid part of a monoacyl glycerol (in $\mathrm{CD}_{3} \mathrm{OD}$ ) [6]. Based on the MS and NMR data compound 1 was identified as 1-palmitoylglycerol.<smiles>C[13CH2]CCCCCCCCCCCCCC(=O)OCC(C)CO</smiles>

The ${ }^{1} \mathrm{H}$ and ${ }^{13} \mathrm{C}$ NMR data of isolated compounds $2-4$ were identical with those of $\beta$-sitosterol (2) [11], (-)-epicatechin (3) [16] and procyanidin B5 (4) [2].<smiles>CC[C@H](CC[C@@H](C)[C@H]1CC[C@H]2[C@@H]3CC=C4C[C@@H](O)CC[C@]4(C)[C@H]3CC[C@]21C)C(C)C</smiles>

2<smiles>Oc1cc(O)c2c(c1)O[C@H](c1ccc(O)c(O)c1)[C@H](O)C2</smiles>

3<smiles>Oc1cc(O)c2c(c1)O[C@H](c1ccc(O)c(O)c1)[C@H](O)C2c1c(O)cc2c(c1O)C[C@@H](O)[C@H](c1ccc(O)c(O)c1)O2</smiles> 
Previously, anthraquinones (chrysophanol, rhein, emodin, physcion and their glycosides), phenolic acids (caffeic, gallic and $p$-hydroxybenzoic acid), flavonoids [quercetin, myricetin, rutin, isorhamnetin, $(+)$-catechin, and (-)-epicatechin gallate] were identified from the plant [8]. This was the first time that 1-palmitoylglycerol (1), $\beta$-sitosterol (2), epicatechin (3) and procyanidin B5 (4) were isolated from the roots of $R$. thyrsiflorus. In our previous investigations, (-)-epicatechin (3) possessed antibacterial activity against MRSA at concentration $100 \mu \mathrm{g} / \mathrm{mL}$ [10], and antiproliferative effect on parental L5178 $\left(\mathrm{IC}_{50}=8 \mu \mathrm{g} / \mathrm{mL}\right)$ and MDR1-transfected L5178 $\left(\mathrm{IC}_{50}=6 \mu \mathrm{g} / \mathrm{mL}\right.$ ) cells (Table 1). Compound 4 was also effective against MDR lymphoma $\left(\mathrm{IC}_{50}=13 \mu \mathrm{g} / \mathrm{mL}\right)$ cells [9]. The combination of $\beta$-sitosterol (2) and stigmasterol showed antitumor activity against $\mathrm{A} 431\left(\mathrm{IC}_{50}=2.62 \mu \mathrm{M}\right)$ and MRC-5 $\left(\mathrm{IC}_{50}=11.31 \mu \mathrm{M}\right)$ human tumour cell lines [3]. Finally, (-)-epicatechin (3) possessed marked $\left(\mathrm{IC}_{50}=2.04 \mu \mathrm{M}\right)$ xanthine oxidase inhibitory activity [14].

Based on the above-mentioned data the isolated compounds can be at least partly responsible for the antibacterial and antiproliferative activities of the plant.

Table 1

Pharmacological activity of the isolated compounds

\begin{tabular}{|c|c|c|c|}
\hline Compound & Pharmacological effect & Cell line & Reference \\
\hline 2 & $\begin{array}{c}\text { antiproliferative activity } \\
\text { in combination with stigmasterol }\end{array}$ & $\begin{aligned} \text { A431 }\left(\mathrm{IC}_{50}\right. & =2.62 \mu \mathrm{M}) \\
\text { MRC-5 }\left(\mathrm{IC}_{50}\right. & =11.31 \mu \mathrm{M})\end{aligned}$ & [3] \\
\hline \multirow{3}{*}{3} & antibacterial activity & MRSA $(100 \mu \mathrm{g} / \mathrm{mL})$ & [10] \\
\hline & antiproliferative activity & $\begin{array}{c}\text { parental L5178 }\left(\mathrm{IC}_{50}=8 \mu \mathrm{g} / \mathrm{mL}\right) \\
\text { MDR1-transfected L5178 } \\
\left(\mathrm{IC}_{50}=6 \mu \mathrm{g} / \mathrm{mL}\right) \\
\end{array}$ & [9] \\
\hline & $\mathrm{XO}$ inhibitory activity & $\mathrm{IC}_{50}=2.04 \mu \mathrm{M}$ & [14] \\
\hline 4 & antiproliferative activity & MDR lymphoma $\left(\mathrm{IC}_{50}=13 \mu \mathrm{g} / \mathrm{mL}\right)$ & [9] \\
\hline
\end{tabular}

\section{ACKNOWLEDGEMENT}

A. V. acknowledges the award of a János Bolyai scholarship of the Hungarian Academy of Sciences.

\section{REFERENCES}

1. Allen, D. E., Hatfield, G. (2004) Medicinal plants in folk tradition - An ethnobotany of Britain and Ireland. Timber Press, Portland, Cambridge.

2. Cui, C. B., Tezuka, Y., Kikuchi, T., Nakano, H., Tamaoki, T., Park, J. H. (1992) Constituents of a fern, Davallia mariesii Moore. II. Identification and ${ }^{1} \mathrm{H}$ - and ${ }^{13} \mathrm{C}-$ Nuclear Magnetic Resonance spectra of procyanidin B-5, epicatechin- $(4 \beta \rightarrow 8)$-epicatechin- $(4 \beta \rightarrow 6)$-epicatechin, and epicatechin- $(4 \beta \rightarrow 6)$ epicatechin- epicatechin- $(4 \beta \rightarrow 8)-(4 \beta \rightarrow 6)$-epicatechin. Chem. Pharm. Bull. 40, 889-898.

3. Csupor-Löffler, B., Hajdú, Z., Zupkó, I., Molnár, J., Forgo, P., Vasas, A., Kele, Z., Hohmann, J. (2011) Antiproliferative constituents of the roots of Conyza canadensis. Planta Med. 77, 1183-1188.

4. Dénes, A., Papp, N., Babai, D., Czúcz, B., Molnár, Z. (2013) Edible wild plants and their use based on ethnographic and ethnobotanical researches among Hungarian in the Carpathian Basin. Dunántúli Dolgozatok (A) Természettudományi Sorozat 13, 35-76. 
5. Getie, M., Gebre-Mariam, T., Rietz, R., Höhne, C., Huschka, C., Schmidtke, M., Abate, A., Neubert, R. H. H. (2003) Evaluation of the antimicrobial and anti-inflammatory activities of the medicinal plants Dodonaea viscosa, Rumex nervosus and Rumex abyssinicus. Fitoterapia 74, 139-143.

6. Hirao, S., Tara, K., Kuwano, K., Tanaka, J., Ishibashi, F. (2012) Algicidal activity of glycerolipids from brown alga Ishige sinicola toward red tide microalgae. Biosci. Biotechnol. Biochem. 76, 372374.

7. Lajter, I., Zupkó, I., Molnár, J., Jakab, G., Balogh, L., Vasas, A., Hohmann, J. (2013) Antiproliferative activity of Polygonaceae species from the Carpathian Basin against human cancer cell lines. Phytother. Res. 27, 77-85.

8. Litvinenko, Y. A., Muzychkina, R. A. (2003) Phytochemical investigation of biologically active substances in certain Kazakhstan Rumex species. 1. Chem. Nat. Comp. 39, 446-449.

9. Martins, A., Vasas, A., Schelz, Z., Viveiros, M., Molnár, J., Hohmann, J., Amaral, L. (2010) Constituents of Carpobrotus edulis inhibit P-glycoprotein of MDR1-transfected mouse lymphoma cells. Anticancer Res. 30, 829-836.

10. Martins, A., Vasas, A., Viveiros, M., Molnár, J., Hohmann, J., Amaral, L. (2011) Antibacterial properties of compounds isolated from Carpobrotus edulis. Int. J. Antimicrob. Ag. 37, 438-444.

11. Ododo, M. M., Choudhury, M. K., Dekebo, A. H. (2016) Structure elucidation of $\beta$-sitosterol with antibacterial activity from the root bark of Malva parviflora. SpringerPlus 5, 1-11.

12. Orbán-Gyapai, O., Lajter, I., Hohmann, J., Jakab, G., Vasas, A. (2015) Xanthine oxidase inhibitory activity of extracts prepared from Polygonaceae species. Phytother. Res. 29, 459-465.

13. Orbán-Gyapai, O., Liktor-Busa, E., Kúsz, N., Stefkó, D., Urbán, E., Hohmann, J., Vasas, A. (2017) Antibacterial screening of Rumex species native to the Carpathian Basin and bioactivity-guided isolation of compounds from Rumex aquaticus. Fitoterapia 118, 103-106.

14. Özyürek, M., Bektaşoğlu, B., Güçlü, K., Apak, R. (2009) Measurement of xanthine oxidase inhibition activity of phenolics and flavonoids with a modified cupric reducing antioxidant capacity (CUPRAC) method. Anal. Chim. Acta 636, 42-50.

15. Pardo-de-Santayana, M., Tardío, J., Morales, R. (2005) The gathering and consumption of wild edible plants in the Campoo (Cantabria, Spain). Int. J. Food Sci. Nutr. 56, 529-542.

16. Shahat, A. A. (2006) Procyanidins from Adansonia digitata. Pharm. Biol. 44, 445-450.

17. Vasas, A., Orbán-Gyapai, O., Hohmann, J. (2015) The genus Rumex: Review of traditional uses, phytochemistry and pharmacology. J. Ethnopharmacol. 175, 198-228. 